\title{
Changing experiences of being, becoming, and belonging: teachers' professional identity revisited
}

\author{
Jeppe Skott ${ }^{1}$ (D) \\ Accepted: 21 October 2018 / Published online: 25 October 2018 \\ (c) The Author(s) 2018
}

\begin{abstract}
Teacher identity has become important in mathematics education research, but mainly in relation to programmes for teacher education (TE) and professional development (PD). Less attention has been paid to understanding the role and development of identities in the majority of cases in which teachers are not involved in long-term TE or PD. This paper presents a study that seeks to develop such understandings. The study defines teacher identities as their shifting experiences of being, becoming and belonging related to the profession. It is a longitudinal case study of a novice teacher, Anna, and it asks how Anna's identities change over the first 4 years of her career at her school, Northgate. To address the question I use a framework called Patterns of Participation (PoP) in combination with a range of methods, including interviews with Anna, her closest colleagues and the leadership at her school, and observations of Anna's classrooms and of team meetings. I argue that this combination invites new understandings of identity development, because it does not prioritise teacher engagement in one particular practice (e.g., as promoted by PD), but allows interpretations of how Anna's engagement with a multitude of different practices play a role for her professional experiences. The results suggest that in general terms, Anna's identity changes from being 'a mathematics teacher at Northgate' to becoming 'a mathematics teacher at Northgate'.
\end{abstract}

Keywords Professional identity $\cdot$ Novice teachers $\cdot$ Mathematics $\cdot$ Patterns of participation $\cdot$ Teacher development

\section{Identity as experiences of engagement in professional practices}

Professional identity is an important notion in educational scholarship. The concept has been used to develop understandings of teachers and teaching in periods of transition or transformation, for instance when novices leave teacher education (TE) and take up their first teaching position; when experienced teachers engage in comprehensive programmes for professional development (PD); or when new curricular materials are introduced. Another characteristic of the field is that it is inspired by social interpretations of human functioning, to a greater extent than other research on and with teachers (Skott 2013).

In what follows I report on a longitudinal case study that shares the two characteristics mentioned above. The study adopts a social perspective to understand how the

Jeppe Skott

jeppe.skott@lnu.se

1 Department of Mathematics Education, Linnaeus University, 35195 Växjö, Sweden professional identities of a novice teacher, Anna, change over the first few years of her career at a Danish primary and lower secondary school, Northgate. Professional identity is defined as Anna's shifting experiences of being, becoming, and belonging as they relate to the profession. It follows that identities are often emotionally laden and evolve in and from interactions with the students, her colleagues, the leadership, and others at the school. The emphasis on interaction, however, does not exclude Anna's personal history and issues beyond the immediate social encounter. On the contrary, the intention is to develop understandings of whether, and how, her current experiences relate to and draw upon different social constellations at and beyond the school, including for instance her previous teacher education programme. I use a framework called Patterns of Participation (PoP) that does not prioritise a particular pre-specified practice (e.g., from a PD initiative or the school), but focuses on how different social constellations and practices come to play a role for Anna's shifting experiences of herself as a teacher.

In order to understand her professional life, I conducted interviews with Anna, with her closest colleagues, and with the school leadership, and I made observations of Anna's 
teaching and of her participation in team meetings. I had previously analysed aspects of the practices that emerged in Anna's classroom in the first half of the study (Skott 2013). In this paper, I do not draw on classroom observations to any great extent. Primarily based on the other data sources and capitalizing on the longitudinal element of the study, I address the question of what characterises Anna's identity trajectory, that is, the development of her professional experiences of being, becoming and belonging, as a teacher at Northgate.

\section{Research on teachers' professional identities}

In the case of novice teachers, important themes in identity studies include the link between identity and teacher attrition (Cochran-Smith et al. 2012); the tensions that arise as teachers are confronted with the challenges of their new profession (e.g., Pillen et al. 2013); and the significance of emotional events for professional identity (Nichols et al. 2016). As these themes indicate, the questions addressed concern how identities shape and are shaped by the experiences and decisions of the novice in the new institutional setting.

In mathematics education the interest in professional identity is often fuelled by attempts to understand the role of TE or PD programmes in learning to teach, sometimes coupled with concerns for why suggestions for reform promoted by such programmes may not find their way into the participating teachers' classrooms. This is so in studies of prospective teachers (Horn et al. 2008; Kang and Battey 2017; Ma and Singer-Gabella 2011), of novices (Jong 2016; Losano et al. 2018), and of experienced teachers (Battey and Franke 2008; Cobb and Gresalfi 2011; Hodgen and Askew 2007). As Battey and Franke (2008) wrote "there remains a large and often undocumented variability in how teachers make use of ideas learned" (p. 127). Battey and Franke seek to understand and support changes in the identities of teachers, who participate in a PD initiative. The histories of mathematical engagement of the two teachers in the study are at odds with the intentions of the PD-programme. Battey and Franke use identity to "document, analyse, and understand teacher learning and classroom practice" (p. 127). Also, they consider how their new understandings may improve the design of future development initiatives. These two intentions are in line with many studies of professional identity. It is, then, one of the paradigmatic questions and an important rationale for a significant part of the field whether a TE or PD-initiative facilitates identity change so as to support teachers in relating productively to the intentions of the reform.

A multitude of terms and definitions have been used about the construct of teacher identity (Lutovac and Kaasila 2017).
In spite of this variability, the studies referred to above indicate that the field is generally informed by social interpretations of human functioning. There seem to be three aspects to this. First, identities are understood as multiple, evolving, and constructed in interaction, rather than as stable and somewhat resilient personality traits. There is, then, often an element of situatedness involved. Second, and in spite of the emphasis on immediate interaction, the social perspective on identity also encompasses how broader culturally organised activity and modes of reasoning inform action and sensemaking. Experiences of being and becoming a teacher are not independent of broader discourses on what it means to teach and of the societal position of teachers in the context in question. And third there is an element of agency involved in identity. Both the immediate and broader social contexts orient teachers' actions, but do so in open-ended ways, leaving space for professional decision-making and agency. Experiences of this agentic space and of the outcomes of manoeuvring within it are aspects of identity.

Developing this social perspective, identity studies in mathematics education draw on different versions of discourse analysis (e.g., Cobb and Gresalfi 2011; Hossain et al. 2013), positioning theory (e.g., Arvaja 2016; Wagner and Herbel-Eisenmann 2009), social practice theory ${ }^{1}$ (e.g. Battey and Franke 2008; Buchanan 2015; Graven 2004) and other extensions of Vygotsky's sociocultural theory (e.g., Bennison 2015). Although different, these frameworks all contrast with more cognitive ones, as they do not focus only on individual actors and their thinking and development. Russ et al. (2016) comment that situative and sociocultural approaches "draw the circle wider [than individual cognition] and seek to place thinking agents in their larger social, physical, cultural, and historical contexts" (p. 403). This applies also to the other frameworks mentioned above. From this perspective social contexts are not viewed as external frames for or challenges to the autonomous cognitive activity of the individual. Rather, the more social approach implies "the situatedness of knowledge, of schooling as social production and reproduction, and of the development of identity (or identities)" (Lerman 2006, p. 172).

Social interpretations of identity supplement and challenge the acquisitionist underpinnings of the majority of studies of teachers' knowledge and beliefs (Skott 2013). The

\footnotetext{
1 The term social practice theory is used about "a historical, material theory of social practice that integrates the study of persons, local practice, and long term historically institutionalized struggles" (e.g., Holland and Lave 2009, p. 1). The term "social practice" may seem redundant as practice is in this view social by definition. However, the phrase explicates that no individual has ownership of a practice, in spite of the significance of individual agency. Also, it serves to distinguish this perspective from other (social) approaches to practice, indicating that there is no unified theory of practice.
} 
two latter fields are generally more cognitive and locate their respective key constructs within the individual. In comparison, identity studies emphasise a person-context interface and consider professional identities to be a process and outcome of participation in social practices. In many studies, teaching is seen as a task that requires teachers to coordinate their engagement in two distinct practices, that of the TE or PD programme and that of the school. As Battey and Franke (2008) point out, teachers return to their schools from PD with new ideas and perspectives on mathematics, but need to

interact with an established context, containing established norms, co-constructed with a group of students. [...] Teachers are taking practices from one context and dropping them into a different social setting that can have very different meanings about engaging in content. (p. 146).

Consequently, Battey and Franke argue, PD must "allow teachers to make sense of their knowledge, skills, and identities in relation to norms in both professional development and classroom practice" (p. 147).

There are obvious potentials in seeking to understand the ways in which aspects of a TE or PD programme support teachers in promoting the intentions of the reform. In spite of that, there is no element of intervention in the study of Anna at Northgate, and the study does not focus in particular on the significance of such a programme. The rationale of the study is the development of understandings of mathematics teachers' professional identities in the vast majority of cases in which they are not involved in long-term TE or PD. In terms of the three elements of the identity construct mentioned previously, it is to understand experiences of being, becoming and belonging as teachers engage with opportunities for agency that evolve in the social setting of the school. To develop such understandings there is a need to supplement the frameworks that are often used in studies of teacher identity in mathematics education.

\section{Framework}

The social stance that dominates current studies of professional identity is reflected in frequent references to social practice theory, most notably the work of Lave, Wenger, and Holland and colleagues (e.g. Holland et al. 1998; Lave 1988, 1997; Lave and Wenger 1991; Wenger 1998). One characteristic of social practice theory is its emphasis on the locally social, that is, on how learning, knowing, and identity are inherently linked to practices as they unfold in a particular situation. This perspective does not disregard the role of macro-level social structures and of power relations, but it suggests that it is an empirical question whether, and how, they play a role for the local emergence of identities (Holland and Lave 2009; Wenger 2010).

The emphasis on local practice is apparent in definitions and descriptions of identity in social practice theory. Identity is seen as a dynamic and ever-evolving construct that is constantly negotiated as people engage with one another. Lave (1996b), for instance links identity to learning. She studied tailors in Liberia and suggested that the telos of an apprentice's learning is to become an accepted participant in the practice of tailoring and to develop a sense of mutual recognition with masters of the trade. This, she wrote, "might even be a reasonable definition of what it means to "construct identities in practice"” (p. 157).

Also linking identity and learning, Wenger (1998) wrote that his work on communities of practice starts with the assumption that "engagement in social practice is the fundamental process by which we learn and so become who we are" (text inside the front cover). Further, he wrote, identity is a "layering of events of participation and reification" connected to a practice (p. 151). Still according to Wenger, participation and reification are also the two constituent elements of meaning as it evolves when one engages with others in a practice. Identity, then, may be viewed as the meaning of 'who we are' that emerges in a particular context.

Holland et al. (1998) define identity as 'imaginings of self in worlds of action' (p. 5). They refer to their version of the three aspects of identity mentioned earlier as three 'contexts of activity'. One is that people engage with one another in immediate interaction and position each other in the process. A second context is figured worlds, that is, "socially and culturally constructed realm[s] of interpretation, in which particular characters and actors are recognised, significance is assigned to certain acts, and particular outcomes are valued over others" (p. 52). Holland et al. mention caste systems in Nepal, Alcoholics Anonymous in the US, and romance at a university campus as examples of figured worlds. In mathematics education, the notion of a figured world has been used concerning "the reform" (Horn et al. 2008; Ma and Singer-Gabella 2011). Third, Holland et al. refer to authoring. This resembles the understanding of agency referred to previously. As Holland et al. put it, in any situation, " $[\mathrm{t}] \mathrm{he}$ world must be answered-authorship is not a choice-but the form of answer is not determined" (p. 272).

\subsection{Patterns of participation}

Like many other studies of professional identity, the one of Anna at Northgate draws on the notions of practice and figured worlds in social practice theory. However, and as mentioned before, the emphasis is not on Anna's relationship to a predefined figured world (e.g., the reform) or on how she moves-or does not move-towards more comprehensive participation in a particular practice (e.g., from 
a PD). The study concerns Anna's experiences as she draws on a multiplicity of prior and present practices and figured worlds when facing the challenges of her new profession. For that purpose I need a framework that focuses on and in some sense re-centres the individual, in this case Anna, as she moves in and out of different social constellations at Northgate. The Patterns-of-Participation framework (PoP) seeks to do that. ${ }^{2}$

PoP supplements the notions of practice and figured worlds from social practice theory, with the notion of self in Chicago-school symbolic interactionism (SI) (Blumer 1969; Mead 1913, 1934). In SI self is a dynamic process and product of action and simultaneous reflection on action. It has two phases, an $I$ and a $m e$. The I acts (does, says, thinks), but instantaneously takes the attitude of others to itself and becomes a me. Interaction, then, is based on individuals' engagement in a double process of (1) acting, which includes indicating to others what to do, and (2) interpreting others' actions symbolically, including their actual or possible reactions to one's own behaviour. Meaning and action, then, are inherently linked and emerge in the process, while informed in open-ended ways by traditions and norms established in and by histories of previous interactions.

The others, whose attitude to oneself one takes in an interaction, may be immediate, individual interlocutors. However, they may also be generalised others, that is, the result of "crystallizing all these particular attitudes into a single attitude or standpoint" (Mead 1934, p. 90). As Simpson (2009) pointed out, a generalised other is a set of "generalized attitudes, or discourse, of a social group or community" (p. 1335). It is a premise of PoP that other past and present practices and figured worlds may function as generalised others and inform interpretations of the situation as it unfolds in any instant. They may, then, play a part in how teachers' contribute to an interaction, and in their emerging professional experiences.

Consider, for example, a teacher who works with a group of elementary students, who are trying to figure out whether their observation is right that the difference between two consecutive perfect squares is the sum of the bases. The teacher may consider reasoning and proving important in school mathematics, and he may be able to prove the result both algebraically and by using a generic, geometrical argument. In the classroom, however, he anticipates and interprets the students' verbal and physical gestures-their words, their tone of voice, their raised eyebrows. Also, he may take the attitude to himself of the reform as promoted in his TE programme, of close colleagues who focus more

\footnotetext{
${ }^{2}$ See Skott (2018) for a discussion of frameworks and for a comparison of PoP and other frameworks used to study identity in mathematics education.
}

on the students' well-being than on their subject-matter learning, or of parents at a recent PTA meeting in which the teacher's professional and mathematical competence was challenged. Depending on the role as generalised others of any or all of these social constellations - or of any other ones he may draw on in the process-his contributions to the interaction may change, for instance making him decide to accept an empirical argument for the students' observation.

The example above indicates that practices and figured worlds beyond the immediate situation may orient a teacher's contributions to an interaction and change his professional experiences in the process. PoP offers a perspective on whether, and how, this is so. In longitudinal studies, PoP is also able to shed light on the changes that occur in and among these practices and figured worlds over time. It follows that the unit of analysis is the individual in interaction, including the prior and present practices and figured worlds she may draw upon as generalised others.

To reiterate, the purpose of combining concepts and processes from social practice theory with SI is to re-centre the individual, while keeping the participatory stance of other studies of identity (Skott 2018). Social practice theory seeks to explain how social practices develop and how individuals move towards more comprehensive participation in one particular practice (e.g., claims processing at an insurance company, cf. Wenger 1998) or alignment with one particular figured world (e.g., caste systems in Nepal, cf. Holland et al. 1998). The notion of self in SI allows a perspective on how communities of practice and figured worlds beyond the present situation may function as generalised others for a teacher, and inform her interpretations of and contributions to the immediate interaction.

The combination of social practice theory and SI in PoP has consequences for the methodology.

\section{Methodology}

The study of Anna at Northgate spans 4 years. Anna responded to a questionnaire at the time of her graduation, and together with six other respondents she was selected for initial interviews concerning the following: their experiences with mathematics in school and at college; mathematics as a school subject and mathematics teaching and learning; and their expectations, hopes, and worries with regard to their new profession. The interviewees were all from a prestigious college in Denmark, and they were to be middle and lower secondary teachers of mathematics and of two or three other subjects. Anna's other subjects are history and a combined course in physics and chemistry.

Anna was selected for the continued study as the only research participant. In the questionnaire and in the first interview she was very committed to teaching, enthusiastic 
about taking up the challenges it would entail, and confident that she could do it well. Also, Anna already had some experiences with teaching. 18 months before her graduation she accepted a part-time position teaching mathematics and science six lessons a week at a nearby municipal school, Northgate Primary and Lower Secondary School. When she graduated, she happily accepted the offer of a permanent position at Northgate.

The main data on Anna are from individual interviews and from observations of her mathematics classrooms. However, it is a defining characteristic of case studies that they are concerned with a specific case in some context. The study of Anna at Northgate obviously delimits the context to the school. In line with social practice theory, however, 'context' is in the present study understood more as how 'people live in history' than as how 'people live in history' (Lave 1996a, p. 21, emphasis in original). This means that the context of Anna's professional life is the variable sense she makes of the setting as she interacts with others at, or in relation to, the school.

It follows from the discussion of symbolic interactionism (cf. Sect. 3) that practices and figured worlds beyond the immediate situation may function as generalised others for Anna and in this sense become important parts of the context. For that reason I use a form of snowballing to include new research participants, when Anna refers to them as significant others for her professional life. In the first interview she mentions her team, that is, a group of three (later four) teachers, who teach (almost) all subjects to a year-group. In subsequent interviews she speaks fondly of the collaboration in the team and of her colleagues in it, leading me to observe team meetings and conduct a group interview with the other team members. Later, Anna repeatedly mentions her participation in short, local PD-sessions, mathematics afternoons, organised by the head of department, and I decided to attend two mathematics afternoons. Still later she refers to the school leadership as important for her position at Northgate, and I conducted a group interview with the headmaster and the deputy head.

The data sources are as follows:

- Seven semi-structured interviews with Anna, three of them with stimulated recall, lasting an average of $63 \mathrm{~min}$. The first interview was conducted at the time of Anna's graduation, the last one 4 years later.

- Observations of 38 lessons (19 sessions of $90 \mathrm{~min}$ ) taught in four periods of $1 \frac{1 / 2-2}{2}$ weeks in four terms beginning in Anna's third term as a full-time teacher at Northgate.

- Informal talks with Anna lasting between 10 and 43 min after approximately half the classroom observations.

- Observations of two meetings in Anna's team.

- Observations of two mathematics afternoons.
- One 45-min semi-structured group interview with the other members of Anna's team.

- One 60-min semi-structured interview with the headmaster and the deputy head.

- Copies of teaching-learning materials.

All interviews were audio recorded and transcribed in full; all classroom observations were video recorded and also transcribed in full. Anna's colleagues do not allow recordings in team meetings and mathematics afternoons, and the data material for those consisted of comprehensive field notes that were elaborated on immediately after each session. Notes were taken from informal talks with Anna and from less systematic observations of her communication with colleagues in the staff-room.

The analysis of the data was conducted without a set of predeveloped codes, and using coding procedures and memo writing inspired by grounded theory (GT) (Charmaz 2014). Initially the data material was coded incident by incident supplemented with line-by-line coding of selected sections. Gerunds were used whenever possible to keep the processual perspective on the data. Examples of initial codes from interviews from the first phase of the study include 'being there as one self'; 'being relaxed with the students'; 'developing confidentiality with students'; 'taking personal responsibility for students', and 'focusing on the personal part of teaching'. Reading across and comparing such codes and the related data sections led to focused codes such as 'building personal relations'. Later in the study, Anna described her commitment to the students somewhat differently, and the category of relationing was developed and included in subsequent analyses to specify its properties, changes in them, and their shifting relationships to Anna's professional experiences over time.

The understanding of identity in the study presented challenges as far as the data generation was concerned. First, Anna's experiences of the current setting was expected to be based also on those for instance from her pre-service education. Indeed, one point of PoP is exactly not to foreground the dominant practice of the arena in question, but to understand how other practices and figured worlds may play a part as generalised others for the teacher. Clearly, I do not have access to these earlier experiences, except in the form of Anna's recollection of her cognitive and emotional involvement. While this may be a poor proxy for how she experienced it at the time, it may provide a reasonable account of their significance for her current professional experiences.

Second, a classroom interaction, an interview situation, a team meeting, and PD session constitute different 'contexts' for Anna, and her identities - as defined in the study-may vary between them. For instance her experiences of belonging and being a competent teacher was probably different when in a team meeting with good colleagues, some of 
whom were close personal friends, from when challenged by students, who are reacting emotionally to not understanding her mathematical explanations. For my present purposes, the interviews with Anna are the main data source. I use other data to understand how other contexts may play a role for her professional experiences as shared in the interviews.

\section{Results and analyses: Anna at Northgate}

Anna was 25 years old when she graduated from college and began to teach full-time at Northgate. Northgate is located in a well-to-do part of a major city in Denmark. It has approximately 750 students from kindergarten to grade 9 with three classes at each grade level. Grades 1-9 are divided into three sections: $1-3,4-6$, and 7-9. The teachers in a section are subdivided into teams that teach (almost) all subjects to the classes in a year group. Anna, the other members of her team, and the leadership all point to the team structure as important for the school. Teams are responsible, for instance, for administrative issues (e.g., time-tables and the organisation of joint activities for the three classes) and the social functioning of the year group.

In her first year at Northgate, Anna taught grade 9 with three colleagues; in her second year the same team took over the three classes in grade 7 . The team followed this group of students until they left the school after grade 9. In the first of these three years Anna taught mathematics to all three classes; in the next 2 years she taught mathematics only in one of them. In all 3 years she was the class teacher in this class, that is, she had the overall responsibility for the class, including how it functions socially and for collaboration with the parents.

Unsurprisingly there are elements of both continuity and change in Anna's professional experiences over the first 4 years of her career. A significant shift occured in the autumn term of her third year. This is at the time of the third set of visits to Northgate and of the fourth and fifth major interviews. I present and discuss the data in two sections on the periods before that and from then onwards.

\subsection{Phase I: 'I'm a mathematics teacher'}

At the time of her graduation Anna considered her college education very important:

You develop so much in those four years [...] I do not feel in any way that I am the same as when I began [...]. There has been so much personal development, but also all the professional stuff. You know, you become someone, who does not only teach some subjects; [being a teacher] has become part of one's identity. (1st interview)
There are four practices or figured worlds that are evident in the interviews from the first phase of the study and that play prominently in Anna's professional experiences at Northgate. These are mathematics, the reform, relationing, and teaming. I present each of them briefly.

Mathematics Anna is explicit that mathematics is important to her. She was good at mathematics in school, and it was always her favourite subject. She repeatedly talks about herself as a mathematics teacher rather than as a teacher who happens to teach mathematics:

I have spent my time at college trying to find the role I want to have as a mathematics teacher. [...] I am not just someone who teaches mathematics, I am a mathematics teacher. [...] [a mathematics teacher is] someone who guards the profession and who burns [with enthusiasm] for it. (1st interview)

It is an important aspect of Anna's experiences of being a good professional that she manages to engage her students in what she regards as proper mathematical activity.

The reform Anna's more specific commitment to mathematics is inspired by current reform efforts. In particular, she refers to the need for the students to communicate about mathematics and to search for 'meaning' by making connections to non-mathematical contexts. Also, it is indicative that she comments on a classroom episode by explaining that her approach was 'probably [based on] the social constructivist in me' (3rd interview). These emphases are also apparent in how she distances herself from what she refers to as 'the exercise paradigm'. This term was used in Anna's college education about teaching that emphasises student command over standard procedures and loses sight of processual aspects of mathematics. Using the term, Anna positions herself within the Danish version of the reform discourse, and simultaneously distances herself from what she sees as the dominant tradition of teaching mathematics among her colleagues. She finds this tradition reflected also in the approach of the students, who focus on readymade solution procedures and results. The extent to which she manages to promote the reform agenda is an important aspect of Anna's professional experiences in this first phase; being able to do so is one reason why she considers herself an important adult to the students.

Relationing The significance of the reform is matched by the enthusiasm with which Anna seeks to build trusting relationships with the students. This goes beyond how they work with mathematics:

My role as a mathematics teacher, I would like that to be important. But it is just as much just being the teacher, and you know, in the way of being together with the students [...] I become mega-important, I really do. (1st interview) 
Becoming "mega-important" involves taking a genuine interest in students' lives and teenage problems. Anna also appreciates that the students are interested in her personal life:

they get interested, and $[\ldots]$ they realise that I am only ten years older than they are $[. .$.$] We have$ many more things in common [than the students and Anna's older colleagues]. (2nd interview)

She says later that her role is being somewhere between a mother and a friend to the students. The experience of being recognized as a teacher, then, depends for Anna at least in part on the extent to which she manages to develop trusting, almost personal relationships with the students.

Teaming Finally, Anna's experiences of being a teacher at Northgate are from the beginning influenced by her team. She explicitly refers to the importance of her collaboration with and support from older team members. One of them, Ian, functions as a role model for Anna and she wants to "maybe copy a little of what he does". This refers to issues such as how Ian organises his work, how he communicates with the parents, and especially how he relates to the students:

[Ian] just knows how to handle the children [...] it is much more all the other stuff than the teaching part $[\ldots]$ it is much more than just how to structure the lesson. (2nd interview)

The concern for individual students' well-being and for the social functioning of the year-group is apparent also in team meetings and in the interview with the other team members. As one of them, Jenny, says, it is characteristic of all teachers at Northgate that they "really think about and care for the children", but even so the team is special:

I know from other colleagues that we are known to be the ones, who always discuss the children during breaks. And we do that a lot.

While Anna's team focuses on the children, it is apparent from the observations of team meetings and from interviews with Anna, with the team, and with the leadership, that the team never discusses the contents of instruction. This is in contrast to other teams at Northgate, and it means that in the two first years of her career, Anna takes all decisions about mathematics in the year group. Because she is convinced that other teachers at the school do not share her approach to the teaching of mathematics, she is not dissatisfied with this situation. In fact, she says, "at least in mathematics, I have been happy to paddle my own canoe" (2nd interview).

\subsubsection{Agency as it relates to teaming, relationing, mathematics, and the reform}

There are, then, two sets of obligations for Anna in the collaboration with the team. On the one hand there are high expectations with regard to how she engages in their joint attempt to support and take care of individual students' well-being and the social functioning of the year group. On the other hand Anna is solely responsible for mathematics in the year group. These aspects of teaming align well with other attitudes Anna takes to herself at Northgate.

With regard to the first obligation, Anna finds it highly compatible with relationing. She contributes enthusiastically to discussions about individual students and about problems among students in team meetings and her more direct involvement with the students' personal problems is in line with the functioning of the team. Also, she seeks a non-authoritarian mode of communication in the classroom, one that disarms potential conflict with the students and that is instrumental in developing mutual trust. Further, there are relatively frequent episodes in which Anna accepts an explanation or a solution from a student even though it does not suffice mathematically (Skott 2013). Commenting on such episodes, she says that it is not good mathematics, and that she accepted the student's response for other reasons. Often she considers the student in question vulnerable and in need of success, possibly just by keeping up with the rest of the class.

The way Anna takes on her obligations related to mathematics fits well with her commitment to the teaching of mathematics and with her confidence that she can do it well. As mentioned previously she draws heavily on the reform discourse in interviews. Sometimes, however, her interpretation of reform recommendations becomes somewhat extreme and loses the subject specificity. For instance Anna argues that there is no need for any standard procedures in mathematics, as long as you know what you are doing. Using division as her example she says:

Ideally, right, if you know what//right down to the bottom of it has this understanding of what it means for example to divide, then you don't need some procedure, cause you know what to do. (3rd interview)

In the same interview she is shown a classroom episode in which the students are to explain to each other how to change from fractions to decimals to percentages. Anna provides few instructions, and in the episode a number of students use terminology and explanations that hardly qualify as mathematical. In the interview, Anna is not worried about the quality of their explanations and she does not feel the need to ensure that they produce better ones. All explanations do not need to meet the same standards: 
I just think that those words [...] I don't know about the quality, maybe it doesn't need to be, not in grade 7 at least, the final truth [...], but if it makes sense to them, if they can put it into words, then I think there is a certain quality in it, if for them, they make an explanation that tells them how to do it. [...] I have no intention of checking, if all those explanations are right or precise, (3rd interview)

To sum up, Anna's professional experiences are in phase I dominated by four aspects of the contexts that emerge: mathematics, the reform, teaming, and relationing. In interviews this is phrased, respectively, as for instance 'I am a mathematics teacher', 'the social constructivist in me', 'copy a little of what Ian does', and 'being somewhere between a mother and a friend'. As indicated above, these different aspects function as generalised others and suggest different attitudes Anna may take to herself. They invite and allow for different forms of agency and mutually transform each other, for instance when relationing leads Anna to accept wrong or incomplete mathematical solutions because she at the instant prioritises not to jeopardise her relationship with weak and vulnerable students. Drawing on these four aspects when working with her students and with the other team members, she develops a profound and somewhat emotional experience of being recognised as a professional and of belonging at Northgate. As she says in an interview in the middle of phase I:

I hope it is obvious that I'm flourishing here, 'cause I really am [...] I have found just the right place for me, both in teaching and at this place [Northgate]. (2nd interview)

\subsection{Phase II: 'I am not new anymore, you know'}

Towards the end of the autumn term of Anna's third year of full-time teaching, there is a significant shift in how she talks about her professional life. She is more pleased than ever with Northgate, but the practices and figured worlds that she draws on change and so do the relationships among them. There are three mutually dependent aspects to this. First, the somewhat extreme interpretation of the reform in Anna's communication about mathematics is modified. Second, relationing is still prominent, but its character changes as her sense of responsibility towards the students becomes less personal and more institutionalised. Third-and co-determining the two other changes-Anna's engagement with team activities is now aligned with and embedded in other professional experiences at Northgate.

\subsubsection{Mathematics—the department and the reform}

From the beginning of Anna's third year at Northgate, another new teacher, Christian, and the head of department, Dan, take over one class each in mathematics from Anna. Although they, according to Anna, teach very differently from herself, she has realised that their "basic views of mathematics are not terribly different" from her own (4th interview). Especially, she says, she and Christian complement each other well. From then on, the three of them meet now and then to organise joint activities for the three classes. Also, Dan invites Anna to hold a workshop on GeoGebra for all mathematics teachers at Northgate at a mathematics afternoon. Commenting on how she has gained a different position in the department and that she now values working with her colleagues in it, Anna says:

And then I have positioned myself more strongly among my colleagues [...] I can feel that there is quite some regard for what I am and what I can contribute [...] at least some of my colleagues now have some respect, as they know my academic level in mathematics is high. (7th interview)

In the same term Anna begins to talk differently about her teaching of mathematics. Already in the second interview (i.e. in the middle of phase I) she said that her inspiration from the reform did not work equally well in all classes, but at that time she did not reconsider her perspective on school mathematics: "I [would] do the same next time" (2nd interview). Now this changes. An indicative example from an interview contrasts with the one referred to earlier (cf. Sect. 5.1.1). In a classroom episode on scales and measurement the students are once again asked to discuss the contents among themselves. However, Anna gives a more substantial introduction to the topic than in previous episodes and after the students' group work she seeks to qualify their explanations in a whole-class setting. Without being prompted, Anna comments in the interview on the difference from what she has done before. She says that if she does not introduce new contents properly, it is

really difficult to ensure that communication is at a sufficiently high level. And that is why I also wanted to pick up on it towards the end. [...] Because I had written down the short definitions from the beginning, they all had words to communicate with. [...] that meant that what they all wrote was of pretty high quality. [...] when you have to practice [talking mathematics] then there needs to be something ... [for them to build on]. (5th interview)

Anna is, then, now concerned with the subject specific quality of students' communication: she seeks to ensure not 
only that that the students communicate, but that their communication qualifies as mathematical.

\subsubsection{Relationing}

The character of Anna's involvement in relationing also changes, both in team meetings and in interviews. She is not dissatisfied that the students to a lesser extent share their problems with her:

They still tell me a lot of things, but maybe not quite so much [as before], like'Maybe Anna doesn't need to know everything'. I think that is quite nice. Otherwise I end up carrying it all around with me as a burden somehow. (the 4th interview)

Also, Anna is less inclined to consider it her obligation to solve the students' personal problems. Instead she increasingly considers whether students need other support, for instance from a psychologist (e.g., 2nd team meeting and 5th interview). Clearly, this change may occur as Anna is now more aware of alternatives to her personal involvement. However, it seems compatible with changes in how she reacts to the students themselves, for instance if they lack concentration or disturb others. She no longer tends to find excuses for them that suggest a personal and somewhat emotional involvement on her part. To a greater extent she points to the students' own responsibilities, to some extent blaming them for not being serious. For instance she comments on a situation in which two girls disturb others: "I think they are stupid [in this situation] and they know perfectly well that I do [think they are stupid]" (5th interview). Anna hardly ever used terminology similar to this statement in phase I.

Later Anna is explicit about her changing relationships with the students. At the time of the last interview the students she has followed for the last 3 years have just left Northgate, and Anna and her team have taken over a new cohort of grade 7 students. Anna, who is now 29, says:

When I look in the mirror, I can tell that I am not 20 anymore. $[\ldots]$ And now I have students who are three years younger [than the ones I had last year] [...] Now we [Anna and Christian] are almost closer to the age of the parents than to the age of the students. We have not tried that before. It wasn't like this. We were more ...

Interviewer: I remember you said [...] years ago [...] that you were pretty close to the students' age, and that you regarded yourself as half a friend.

Anna: Yes, that could be a danger at times.

JS: Or an advantage, if I understood you correctly?

Anna: Yes, that is right. That is how I saw it. [Now] there is a different relation to the students. (7th interview).

\subsubsection{Positioning herself at Northgate}

A third shift in Anna's experiences at Northgate relates to her general position at the school and concerns the Northgate spirit. The Northgate spirit is a recurrent theme in later interviews with Anna as well as in the ones with the team and the leadership. One aspect of it is that it is a privilege to work at Northgate, but one that comes with some obligations.

The leaders agree that they are able to hire only the best and most ambitious teachers. In addition they are explicit that they put pressure on them to make them perform well, "not just mild pressure". The deputy explains:

There is a high level of ambition [...] It is special to work here, you know. The school has a good reputation; the teachers have a good reputation. [...] and they are, they are something special. [...] there is certainly this sense among the teachers that they are good. And they are. They are special.

The level of ambition is also mentioned by Anna's team as an aspect of the Northgate spirit:

Jenny: I think it is striking that we are ambitious [...] When you first arrive as a new colleague, you soon realise what this is all about. This is not a place where you can just//

Ian: just sit down and relax.

Jenny: You don't sit down and let things happen. Quite a lot is expected, you know. From the colleagues. From the leadership.

[...]

Ian: As a newcomer you need a certain drive.

But for newcomers, ambition needs to be coupled with humility:

Jenny: You have to be somewhat humble to work here. $[\ldots]$ you cannot just arrive and be a wise-guy and change it all $[\ldots]$ it suits you to take it a little easy.

It appears that Anna has managed to strike the balance between initiative and humility. She is highly appreciated by the other team members and by the leadership. According to the deputy head, she functions well in a team, because she reflects on what she is doing and "enters the collaboration with self-confidence". The headmaster elaborates:

She is probably a pretty good example that a teacher, who is competent and wants [to achieve] something can get the kind of assistance needed to develop.

\subsubsection{Identity shifts}

In the last interview I asked Anna to look back on the first 4 years of her career. She said: 
I see the school a bit in the same way. The fascination you heard me talk about, the history and the spirit of the place and the ambitious teachers and the brilliant leadership. That is how I still feel. [...] But a lot has happened to myself. (7th interview)

She explains how she has positioned herself differently from when she first arrived, not only among the colleagues, but also in relation to the leadership:

[...] I wasn't asked three years ago, but now I'm being called into the [deputy's] office and "how do you see this" [...]. I am a little pushy and, you know, want to ... move ahead ... help or make a contribution. And in that way something happens to my position. People listen to you when you are asked, which I wasn't three years ago. [...]

Somebody is to come from the ministry about the new national syllabus [...] and they are to interview a few of us. And then [the headmaster] asks me, if I would want to do it, and then I can feel, "Okay, you are not new anymore, are you?" (7th interview)

Anna's comments as well as those made by her team and the leadership signal that she has gained a prominent position at Northgate. It is worth noting that she in the last interview refers to how fondly she spoke of the school when she first arrived. However, in the interviews from phase $I$, there is no positive reference to the spirit of Northgate and no mention of the leadership. Although Anna is already then full of admiration for the other members of her team, there is hardly any positive comment about other colleagues. In fact, she explicitly distances herself from what she at the time considers the traditions of teaching mathematics at the school.

It is apparent that the practices and figured worlds that co-constitute the context for Anna's professional experiences at Northgate have partly been replaced or transformed.

- The team is still important for Anna, but teaming is no longer the only significant school-based practice for her. Rather, the team is one of three social constellations that influence her experience of being recognized as a competent colleague and of belonging at Northgate, the other two being the department and the leadership. Teaming is, then, imbedded in a more comprehensive experience of belonging at Northgate and of being recognized as a competent colleague.

As Anna begins to refer to school-based constellations other than the team, the significance and character of the other initial practices and figured worlds change.
- The significance of Anna's version of the reform discourse fades as the temporal distance to her pre-service education increases and her collaboration with colleagues in the department develops. Her interpretations of classroom episodes and of her experiences of doing a good job is now to a greater extent inspired by the latter. In other terms, she now seems more inclined to use distinct social constellations at the school (e.g., the department) as generalised others and less inclined to draw on the reform as promoted by her pre-service education.

- Though Anna still cares for the students and wants to establish a sense of mutual trust and respect, relationing is transformed. She no longer seeks to develop friend-like relationships with them, and relationing becomes less a matter of personal involvement and more one of seeking institutionalised support.

Between them these changes point to a shift of emphasis in Anna's experiences of her professional life. She is now less a 'Mathematics teacher at Northgate' than a 'mathematics teacher at Northgate'.

\section{Discussion}

In a number of ways the study of Anna at Northgate confirms other studies of novice teachers. Pillen et al. (2013) point to the difficulty of establishing a professional authority without being authoritarian and sacrificing the opportunity of close relationships with the students. Although it does not become problematic for Anna, the inherent difficulty is apparent. Cochran-Smith et al. (2012) look at connections between high quality teaching and beginning teachers' propensity to stay in the profession. One of their categories consists of novices who "go strong and stay on". They are characterised among other things by their need for

meaningful professional development and opportunities to collaborate. [...] They also need guidance about how to choose their battles and safeguard personal time (p. 861-862)

Such collaboration and guidance are parts of the support Anna gets from her team all along. Gradually she positions herself and is positioned by the leadership and within the department in ways that significantly extend her collaborative opportunities.

Nichols et al. (2016) investigate emotional events and how they influence novice teachers' identities. For Anna, the emotional attachment to her students (especially in phase I) and the positive response she receives in return are significant elements of her professional experiences at Northgate. Other emotional events include the invitation to present at a mathematics afternoon, to assist the deputy head in various 
ways, and to meet with representatives from the ministry. She accepts each of these with a strong sense of being recognised as a valued teacher and colleague and of belonging at Northgate.

In spite of the similar frameworks, the study of Anna at Northgate differs from most identity studies in mathematics education. First it does not prioritise a pre-defined figured world (e.g., the reform) or the practices that promote it (e.g., a PD). Also, it does not give analytic primacy to dominant practices at Northgate in the sense of seeking first to determine their constituent elements and subsequently describe how Anna moves towards more comprehensive participation in them. Rather, it is an attempt to address a point that Lutovac and Kaasila (2017) made recently:

Although an individual's identity is greatly shaped by the social contexts $[\ldots]$, we believe that by neglecting the individual, i.e. how one thinks and feels and who one is, is at odds with the core concept of identity itself. (p. 9)

The use of PoP in the study is an attempt to re-centre the individual, while maintaining the participatory stance of other studies in the field (Skott 2013, 2018). It is to provide a perspective on whether, and how, other past and present practices and figured worlds function as generalised others for Anna's interpretations of and contributions to her interactions with her students, her colleagues, and the leadership. The sense of agency in the notion of identity is then a matter of how Anna draws on and combines these generalised others, sometimes in unexpected ways, when authoring an answer to the immediate situation (cf. the quotation in section 3 from Holland et al. 1998).

In combination with longitudinal case studies, PoP allows access to changes in and among practices and figured worlds that gain prominence as generalised others. In the case of Anna at Northgate, this includes that teaming is embedded in how she positions herself in the department and in relation to the leadership; how her engagement with mathematics changes as her somewhat extreme interpretation of the reform fades; and that relationing is transformed as she increasingly engages in institutionalised ways of addressing students' problems and to lesser extent take personal responsibility for solving them. Between them these changes suggest how her professional experiences develop over time.

Second, Battey and Franke (2008) argue that TE and PD-programmes need to take it seriously that as teachers interact with their students, they co-construct dominant classroom norms with them. PoP is in line with the view that individual teachers do not have ownership of norms and practices that evolve. However, it is a premise of PoP that to understand how norms and practices emerge as individuals engage with them, one has to look beyond the immediate arena (e.g., a classroom) and include social constellations at the meso- and macro-level to the extent that they prove significant for the study in question.

The case of Anna at Northgate may be considered a critical case (Flyvbjerg 2011). This is so, relative to the question of what and how social practices and figured worlds play a role for her professional identity. Indeed, if the professional identities of a teacher with Anna's background and commitment depend in profound ways on local school practices, including some beyond the classroom, there is little reason to expect that identities of other novices with weaker backgrounds and less commitment do not. One moral of the story, then, is that if TE and PD-programmes are to have an impact they need to take it seriously that the social construction of norms and practices are not limited to the classroom, but involve broader social settings. Also, they need to set more modest aims for their educational initiatives than 'implementing the reform'. Otherwise they will continue to lose sight of the social character of school and classroom practices, irrespective of the social interpretation of the construct of identity.

Open Access This article is distributed under the terms of the Creative Commons Attribution 4.0 International License (http://creativeco mmons.org/licenses/by/4.0/), which permits unrestricted use, distribution, and reproduction in any medium, provided you give appropriate credit to the original author(s) and the source, provide a link to the Creative Commons license, and indicate if changes were made.

\section{References}

Arvaja, M. (2016). Building teacher identity through the process of positioning. Teaching and Teacher Education, 59, 392-402. https://doi.org/10.1016/j.tate.2016.07.024.

Battey, D., \& Franke, M. L. (2008). Transforming identities: understanding teachers across professional development and classroom practice. Teacher Education Quarterly, 35(3), 127-149.

Bennison, A. (2015). Supporting teachers to embed numeracy across the curriculum: A sociocultural approach. ZDM Mathematics Education, 47(4), 561-573. https://doi.org/10.1007/s1185 8-015-0706-3.

Blumer, H. (1969). Symbolic interactionism. Perspective and method. Berkeley: University of Los Angeles Press.

Buchanan, R. (2015). Teacher identity and agency in an era of accountability. Teachers and teaching, 21(6), 700-719. https:// doi.org/10.1080/13540602.2015.1044329.

Charmaz, K. (2014). Constructing grounded theory (2nd edn.). Los Angeles: Sage.

Cobb, P., \& Gresalfi, M. S. (2011). Negotiating identities for mathematics teaching in the context of professional development. Journal for Research in Mathematics Education, 42(3), 270-304.

Cochran-Smith, M., McQuillan, P., Mitchell, K., Terrell, D. G., Barnatt, J., D'Souza, L., et al. (2012). A longitudinal study of teaching practice and early career decisions: A cautionary tale. American Educational Research Journal, 49(5), 844-880. https://doi. org/10.3102/0002831211431006. 
Flyvbjerg, B. (2011). Case study. In N. K. Denzin \& Y. Lincoln (Eds.), The Sage handbook of qualitative research (4th edn., pp. 301316). Thousand Oaks: Sage.

Graven, M. (2004). Investigating mathematics teacher learning within an in-service community of practice: the centrality of confidence. Educational Studies in Mathematics, 57(2), 177-211.

Hodgen, J., \& Askew, M. (2007). Emotion, identity and teacher learning: Becoming a primary mathematics teacher. Oxford Review of Education, 33(4), 369-487.

Holland, D., \& Lave, J. (2009). Social practice theory and the historical production of persons. Actio: An International Journal of Human Activity (2), 1-15.

Holland, D., Skinner, D., Lachicotte Jr, W., \& Cain, C. (1998). Identity and agency in cultural worlds. Cambridge: Harvard University Press.

Horn, I. S., Nolen, S. B., Ward, C., \& Campbell, S. S. (2008). Developing practices in multiple worlds: the role of identity in learning to teach. Teacher Education Quarterly, 35(3), 61-72.

Hossain, S., Mendick, H., \& Adler, J. (2013). Troubling "understanding mathematics in-depth": Its role in the identity work of studentteachers in England. Educational Studies in Mathematics, 84(1), 35-48. https://doi.org/10.1007/s10649-013-9474-6.

Jong, C. (2016). Linking reform-oriented experiences to teacher identity: The case of an elementary mathematics teacher. The Journal of Educational Research, 109(3), 296-310. https://doi. org/10.1080/00220671.2014.947398.

Kang, H. J., \& Battey, D. (2017). Contextualizing the identity development of preservice elementary mathematics teachers in methods courses and mentor teacher support. Journal of Education and Development, 1(1), 24-36. https://doi.org/10.20849/jed.v1i1.248.

Lave, J. (1988). Cognition in practice. Cambridge: Cambridge University Press.

Lave, J. (1996a). The practice of learning. In S. Chaiklin \& J. Lave (Eds.), Understanding practice. Perspectives on activity and context (pp. 3-32). Cambridge: Cambridge University Press.

Lave, J. (1996b). Teaching, as Learning, in Practice. Mind, Culture, and Activity, 3(3), 149-164. https://doi.org/10.1207/s15327884m ca0303_2.

Lave, J. (1997). The culture of acquisition and the practice of learning. In D. Kirshner \& J. A. Whitson (Eds.), Situated cognition. Social, semiotic, and psychological perspecrtives (pp. 17-35). Mahwah: Lawrence Erlbaum.

Lave, J., \& Wenger, E. (1991). Situated learning. Legitimate peripheral participation. Cambridge: Cambridge University Press.

Lerman, S. (2006). Cultural psychology, anthropology and sociology: The developing 'strong' social turn. In J. Maasz \& W. Schlöglmann (Eds.), New mathematics education research and practice (pp. 171-188). Rotterdam/Taipei: Sense.
Losano, L., Fiorentini, D., \& Vilarreal, M. (2018). The development of a mathematics teacher's professional identity during her first year teaching. Journal of Mathematics Teacher Education, 21(3), 287-315. https://doi.org/10.1007/s10857-017-9364-4.

Lutovac, S., \& Kaasila, R. (2017). Future directions in research on mathematics-related teacher identity. International Journal of Science and Mathematics Education. https://doi.org/10.1007/s1076 3-017-9796-4.

Ma, J. Y., \& Singer-Gabella, M. (2011). Learning to teach in the figured world of reform mathematics: Negotiating new models of identity. Journal of Teacher Education, 62(1), 8-22.

Mead, G. H. (1913). The social self. The Journal of Philosophy, Psychology and Social Methods, 10(14), 374-380.

Mead, G. H. (1934). Mind, self, and society from the standpoint of a social behaviorist. Chicago: University of Chicago.

Nichols, S. L., Schutz, P. A., Rodgers, K., \& Bilica, K. (2016). Early career teachers' emotion and emerging teacher identities. Teachers and teaching, 23(4), 406-421. https://doi.org/10.1080/13540 602.2016.1211099.

Pillen, M., Beijard, D., \& den Brok, P. (2013). Professional identity tensions of beginning teachers. Teachers and Teaching, 19(6), 660-678. https://doi.org/10.1080/13540602.2013.827455.

Russ, R. S., Sherin, B. L., \& Sherin, M. G. (2016). What constitutes teacher learning? In D. H. Gitomer \& C. a. Bell (Eds.), Handbook of research on teaching (5th edn., pp. 391-438). Washington D.C: AERA.

Simpson, B. (2009). Pragmatism, Mead and the practice turn. Organization Studies, 30(12), 1329-1347. https://doi.org/10.1177/01708 40609349861.

Skott, J. (2013). Understanding the role of the teacher in emerging classroom practices: Searching for patterns of participation. ZDM-The International Journal on Mathematics Education, 45(4), 547-559. https://doi.org/10.1007/s11858-013-0500-z.

Skott, J. (2018). Re-centring the individual in participatory accounts of professional identity. In G. Kaiser, H. Forgasz, M. Graven, A. Kuzniak, E. Simmt \& B. Xu (Eds.), Invited lectures from the 13th International Congress on Mathematical Education (pp. 601618). Cham: Springer.

Wagner, D., \& Herbel-Eisenmann, B. (2009). Re-mythologizing mathematics through attention to classroom positioning. Educational Studies in Mathematics, 72(1), 1-15.

Wenger, E. (1998). Communities of practice. Learning, meaning, and identity. Cambridge: Cambridge University Press.

Wenger, E. (2010). Communities of practice and social learning systems: The career of a concept. In C. Blackmore (Ed.), Social learning systems and communities of practice (pp. 179-198). London: Springer. 